\title{
Correction to: Role of C-Reactive Protein in Contributing to Increased Cardiovascular Risk in Metabolic Syndrome
}

\author{
Sridevi Devaraj ${ }^{1,2} \cdot$ Simona Valleggi ${ }^{1,2} \cdot$ David Siegel $^{2} \cdot$ Ishwarlal Jialal $^{1,2}$
}

Published online: 25 January 2019

(C) Springer Science+Business Media, LLC, part of Springer Nature 2019

Correction to: Curr Atheroscler Rep (2010) 12:110-118

https://doi.org/10.1007/s11883-010-0098-3

A portion of this article was previously published as part of an article titled "Human C-reactive protein and the metabolic syndrome" in the following journal: Curr Opin Lipidol. 2009 Jun;20(3):182-9. https://doi.org/10.1097/MOL. 0b013e32832ac03e. https://insights.ovid.com/crossref?an= 00041433-200906000-00007.

\section{Publisher's Note}

Springer Nature remains neutral with regard to jurisdictional claims in published maps and institutional affiliations.

The online version of the original article can be found at https://doi.org/ 10.1007/s11883-010-0098-3

Ishwarlal Jialal

ishwarlal.jialal@ucdmc.ucdavis.edu

1 Laboratory for Atherosclerosis and Metabolic Research, University of California Davis Medical Center, 4635 2nd Avenue, Research 1 Building, Room 3000, Sacramento, CA 95817, USA

2 Veterans Affairs Medical Center, Mather, CA, USA 